\title{
Human Rights, Economic Liberalism and Social Affairs in Post-Pinochet Chille*
}

\author{
Gilberto Aranda Bustamante**
}

\section{Abstract}

The Chilean democratisation process sought the international rehabilitation of a country in the declarative triad of human rights, democratic representation and economic liberalism. Since 1994, the country has reached greater prominence through economic diplomacy and the strategy of open regionalism, and with it the influence of business interest groups. This article holds that, additionally, the human rights movement gave the civilian governments a stamp of symbolic commitment to this issue that, at the turn of the century, led to Chile's active participation in multilateral forums on social inclusion. Additionally, with the turn of the century, the State opened spaces for the interaction of border social groups, particularly the ethnic groups, with which they had cultivated strong transnational dynamics.

Keywords: Chile, Human Rights, Neoliberalism, Regionalism, Paradiplomacy Integration.

\section{Introduction}

Reverberation is an acoustic phenomenon that points to the reflection of a sound wave that remains in time, even though the

\footnotetext{
* Received on 26 October 2015 and approved for publication on 22 February 2016.

** University of Chile, Santiago, Chile; garanda@uchile.cl.
} 
original source may have stopped emitting it. Foreign policy, far from being a black box is also permeable to domestic social demands that are interpreted and channelled by way of results (Easton 1963). Often, the set of two domestic-international levels (Putnam 1988), explains that social requirements bounce against specific goals designed by the ruling groups and elites, remaining as echoes of social demands. However, other social requirements are incorporated as part of foreign policy, persisting as an image, a symbol, or an active compromise of the State.

The possibility of society participating in the foreign policy of a State is based on different traditions: the liberal institutionalist who sees civil society as a sector that can influence political dynamics (Wapner 1997: 70); the liberal conservative perspective that in the binary tradition between the state of nature and the polis, insists on the formative graduality and the smaller manipulability regarding public policies of the former (Fukuyama 1995: 7), without forgetting heterodox Marxist perspectives that stressed that in 'the West' the social agency claimed more relevance compared with the State (Anderson 1981:23) stating that the key for governing a society rests upon the principle of consensus as the broad principle of social legitimacy (Portantiero 1981: 76-78).

An example of this social consensus giving legitimacy occurred in Chile during the time of the military regime (1973-1990), when the opposition had the defence of human rights as its battle flag. In that state of affairs former political adversaries, like the centrist Christian Democrats and the Socialist Left worked hard together for the recognition of such universal values, pledging to observe and promote them during a transition to civilian rule. Human Rights provided the core articulating principles of the coalition government that undertook the herculean task of replacing a military regime that had lasted 17 years. 


\section{Human Rights, Economic Liberalism and \\ Social Affairs in Post-Pinochet Chile}

In this regard, one cannot ignore that before the political re-construction, Human Rights had been part of the discourse of the social opposition, backed by the Catholic Church (Aranda 2004), later moving to become a domestic and international imperative and a commitment of the foreign policy of the democratically elected government that took office in March 1990. The appraisal of democracy and the development of an open market economy represented functional factors for the manner and the dimension that Chile had decided to project to the world. This resulted in a cautious diplomatic action in the field of Human Rights, ready to join the international consensus that had been previously reached. That is, in this matter the Chilean government took pains in the search for a national re-legitimisation in international society starting with internal democratic development. In this way, we can understand the early doctrinal incidence of liberalism in a transitional process that was intended to emphasise the liberal theoretical and valoric fundamentals in a foreign policy, and which sought economic integration and a transnational openness of Chilean society in the context of world globalisation.

Also, the kind of complexity displayed by the process and management of Chilean foreign policy over the past quarter century is evidence of this ideological orientation, based on a certain pragmatism that recognises the prevailing conditions in the international system, but without rejecting the social demands so as not to risk the aforementioned kind of international insertion. External decision-makers tested an exterior projection, which combined the domestic progress and consolidation of the political processes and economic development with the agreements signed in the international sphere. From the time of the transition to civilian rule, foreign policy makers have gradually been incorporating into their formal and informal consultation mechanisms certain non-governmental organisations and specific interest groups, 
collecting their concerns, perceptions, motives, claims and assessments about matters that were basically important for the sector. Business organisations have been among the most active, with a minor participation of other types of organisations. After all, business entrepreneurship was a key sector for Chile's nineteenth-century expansion, which even preceded the State in the northern territorial expansion and its projection into the Pacific in the same century. In the latter case, Chilean policy towards the Pacific Ocean was due to commercial reasons, driven by the private sector who demanded the government open consulates and trade offices (Echeverria, Orrego and O'Shea 1982: 12) in remote places such as Auckland, Melbourne, Sydney, Guangzhou, Hong Kong, Manila, Papeete, Honolulu, Bombay, Calcutta and Brunei. The opening of these markets began a commercial traffic, subject to irregular cycles, and dependent on domestic variables and the equation of international complementarity-competitiveness still enshrined in the Chilean presence in the Pacific Ocean.

Today, the influence of the corporate sector is felt acutely not only in one of the major international groups of which Chile is an active member, the Pacific Alliance, but also in State agencies such as the Economic Directorate of the Foreign Ministry (DIRECON). Therefore, it is not surprising to find the pragmatic presence of Chilean foreign policy within the main coordinates of economic globalisation, in line with a multilateralism that responds to its size and geographical position, and the presence of a discourse of regional integration that does not always coincide, in its content, with other dynamic convergences in the region. Therefore, to account for Chile's foreign policy practices involving groups other than the traditional presence of entrepreneurs, we should basically move to the territorial margins, which are considered border societies.

This is facilitated by less conventional theoretical approaches. One example is a post-modern approach that provides us the foundations 
of the incorporation of civilian society into fields traditionally assigned to the State. This is the case of foreign policy and diplomacy.

In this way, an innovative perspective states that diplomatic relations constituted a social tradition of neighbourhood in the old world that preceded the inter-State relationship.

Likewise, the emergence of the modern State, involved the appropriation of the concept and diplomatic practice through intensive territorialisation (Cornago 2009), which led to the estrangement of companies that traditionally cultivated strong ties.

For Latin America in general, and Chile in particular, it is relevant to incorporate into the analysis other non-central government social actors. That, without ignoring the validity of a process, sets diplomacy in strictly governmental spaces and actors, especially during crises with neighbours that present potential conflicts. Within the non-central governmental social actors there are mayors, governors and municipalities, along with employers and union workers. They all interact in the bilateral relations of neighbouring societies while they intend to reconcile diversity (Cornago 2013b).

This new perspective suggests that a crucial historical aspect of diplomacy, and one that could be projected at present, is the mutual recognition and understanding of cultural differences in diverse societies.

In this context, for Montobio, the reason for the existence of diplomacy is based on a perspective of otherness in relations among States and peoples. Although that is not done to overcome this otherness, it is always the source of a desirable improvement (Montobio 2004). Thus, the symbolic importance of inter-dimensional border social relations, which is frequently 


\section{Gilberto Aranda Bustamante}

ignored by the strict utilitarian logic and the calculation of the central state, is confirmed, (Cornago 2013).

However, while encouraged by such utilitarian rational logic, the Chilean State has allowed, and even encouraged, the participation of neighbouring States in the relationship of actors, other than the centrally appointed officials, under a paradiplomatic record file.

The presence of local or regional non-central institutions has led to the formation of more horizontal spaces that extend beyond the hierarchical rigidity of the State by way of a thematic expansion of the foreign policy agenda and above all with the active participation of other base actors. Although this process is mostly led by non-central government known as intendances, governorates and municipalities that are oriented by cooperation, other entities, composed of a part of civil society, are invited to participate, leading to a new dynamic that promotes their legitimacy in external definitions. Starting from Border Committees and Integration and particularly from small groups inhabiting the border areas, the emergence of a responsive paradiplomacy that reacts against the abandonment of regions that are isolated from the decision making centre precisely at a time when the issue of cultural diversity emerges from an ethics that is accepted globally (Lolas 2013). In the specific case of Aymaras sin Fronteras (Aymaras Without Borders) the value of an instrumental and symbolic paradiplomacy is confirmed, which combines utilitarian motives of the economic context with the reproduction of a collective identity, by recovering the ancestral sense of the representation of their culture (Cornago 2010: 123). This text suggests that in these experiences there is also, in its origin, a democratising potential for a foreign policy of social content. Before that, however, we will review some aspects of the courses of action of foreign policies over the last quarter century. 


\title{
Human Rights, Economic Liberalism and \\ Social Affairs in Post-Pinochet Chile \\ Persistence and transformations of the transition: Human Rights in Chilean foreign policy
}

\begin{abstract}
As mentioned above, Chilean foreign policy has been guided for 25 years by certain fundamental principles, such as the promotion of democracy, respect for human rights and the country's active participation in multilateral organisations. Although all these trends have had a high degree of continuity during the period of the coalition governments, each administration has had its own characteristics. As already pointed out, Patricio Aylwin (1990-1994) favoured the consolidation and democratic legitimacy of the new regime, so his foreign policy had a strong political emphasis on the humanitarian recovery of democratic traditions as a response to the social, political, legal and authoritarian legacy of the military regime; his focus on human rights was thus clearly understood.
\end{abstract}

Eduardo Frei Ruiz-Tagle (1994-2000) displayed a kind of 'diplomacy for development', with a preponderance of economic and commercial matters in the international insertion of Chile, building bridges to the region, which explains his support in 1994 for the Southern Common Market (MERCOSUR), and the Free Trade Area of the Americas (FTAA), while adhering to the Asia Pacific Economic Forum (APEC).

Such foreign policy was premised on the political re-insertion into the world and the region that had already been achieved under the previous administration; external links would therefore be conducted in a manner compatible with the economic growth and the diversification of exports. As a result, neighbourhood economic relations experienced a high momentum, with a strong entrepreneurial leadership that invested heavily in Peru and Argentina. 


\section{Gilberto Aranda Bustamante}

Ricardo Lagos (2000-2006) proposed to combine the aforementioned aspects, directing the government's foreign policy on the basis of international political dialogue and trade and economic convergence (Quezada 2010). As a result, Free Trade Agreements (FTAs) were signed with the EU (2002), the USA (2003), South Korea (2003) and China (2006), simultaneously with the will to promote a balanced trade with the areas that Chile had economic relations with. ${ }^{1}$

At the same time, Chile boosted Latin American economic integration and political cooperation, accompanied by the development of modern conceptions of security, in order to strengthen peace and democracy in the region; without forgetting an economic opening linking the country to dynamic centres of growth and technological innovation. Finally, relations based on cooperation and understanding with developing countries were promoted through an active participation in multilateral organisations.

Democracy soon became a slogan of the country's foreign policy that contributed in a fundamental way to its international recognition. This became evident when Chile, along with other countries in the region, approved the Declaration of Santiago on the protection of democracy, within the framework of the Organisation of American States (OAS) in 1991, and included the democratic clauses in signed trade agreements, as was the case with MERCOSUR and the EU.

Aylwin's government had among its main goals the start of an intense process of international re-insertion of the country which, accompanied by a dose of pragmatism, meant the abandonment of traditional conceptions concerning protectionist regional integration. 
The restoration of the democratic government in Chile, in March 1990, confirmed the model of commercial openness to the world, tested by the military regime since the seventies, to which were added the institutions and rules of liberal democracy and human rights. It was also the start of the projection, in the international environment, of the image of a successful country, whose symbol was the so-called 'Chilean model' that combined the liberal economic pattern established during the military regime with a democratic system that was in the process of solidification.

Thus, the administration of Patricio Aylwin was determined to re-insert Chile as an actor at the international level, adhering to global trends with a regional perspective. As a country of small geographical size, Chile favoured its participation in the multilateral arena, transforming it into a cardinal instrument of its foreign policy, based on the existence of clear rules and transparent discipline conferring options on State members. The result was a renewed participation in international forums, candidatures to preside over various organisations and participation in summits and conferences, and presidential tours abroad, all as part of a strategy to regain international prestige. Consequently, foreign policy maintained links with MERCOSUR, the Andean Community (CAN), issues that in the $21^{\text {st }}$ century were reflected first in the commitment to the Union of South American Nations (UNASUR) and then the Summit of Latin America and the Caribbean, that created the Community of Latin American and Caribbean States (CELAC), or the role played by Chile in the UN Stabilisation Mission in Haiti (MINUSTAH).

In the area of Human Rights, all governments that came after the military regime have sought to incorporate this issue through democratic and programmed guidelines. These were understood as the set of ethical demands, existing in various societies, derived from the realisation of historical values such as freedom, equality and security. 


\section{Gilberto Aranda Bustamante}

The first administration of the transition declared that in the external environment it intended to establish a policy based on universal values to ensure international relations that attended Human Rights (Ministry of Foreign Affairs of Chile 1992: 5). Originally, for the administration of Patricio Aylwin, the transition meant that the recovery of Chile's international presence was based on respect for human rights, and it is possible to note that the foreign policy of Chile with regard to human rights was determined by its need for consolidation and democratic legitimacy (Ministry of Foreign Affairs of Chile 1992: 17).

The constitutional reforms aimed at changing Article 5, subsection 2, which by limiting the exercise of sovereignty, recognises respect for fundamental rights that derive from human nature, forcing State bodies to promote notions guaranteed by the Constitution (Constitution Chart of the Republic of Chile 2006: 12), as well as the international treaties in force and ratified by Chile. These international human rights treaties take precedence over domestic laws in Chile.

In this way, in 1991 the Government withdrew the observations made at the time of its ratification in 1988 of the United Nations Convention against Torture and other Cruel, Inhuman or Degrading Acts, and also the Inter-American Convention to Prevent and Penalise Torture. This decision is very crucial, because Chile made a compromise not to exempt from criminal liability those who had taken part, under orders from superiors, in illegal acts such as those detailed in these international instruments

In addition, the government of Patricio Aylwin responded to the grave and massive violations of human rights during the military regime by Supreme Decree No. 355 of 24 April 1990 that formed the Rettig Report. Its aim was to contribute to the comprehensive investigation of such violations. The Commission established a 
picture of the serious acts of violation of Human Rights, history and circumstances; the singling out of victims to collect information and establish their possible whereabouts, recommending remedial compensation to the victims. It also promoted the implementation of legal and administrative measures to prevent or bar the commission of further serious violations of Human Rights. The final result of the investigations of the Commission was a report in three parts: the first addressed the constituent facts of violations of Human Rights, the second the recommendations to repair the damage, and the third the identification of the victims.

The government of Eduardo Frei Ruiz Tagle, even when it followed these guidelines, did not give equal priority in its thematic agenda to Human Rights. However, the thematic contingency resumed with the arrest of Pinochet in London. The former head of state was arrested on 16 October 1998 while recovering from an operation in a clinic. Human Rights had again become a key issue for achieving national co-existence. An emerging transnational justice demanded the creation of international tribunals or courts to study and judge serious crimes against humanity, favouring the victims of countries where they could not find answers in their national courts. Chile reacted by setting up a 'Mesa de Diálogo' ('Roundtable on Human Rights') that included political leaders, the Armed Forces, groups of families of victims of the military regime, and representatives of churches of all faiths in order to work toward national reconciliation on the basis of the clarification of the whereabouts of those who had disappeared and recognition of responsibility for such violations.

The subsequent government of Ricardo Lagos sought to address the issue of Human Rights through a multi-dimensional approach, promoting the integral development of human beings, working for the protection of their civil and political rights, and ensuring the minimum conditions for exercising their economic, social and cultural rights (Lagos 2001). 
Chile agreed with the UN initiative to convene member states to a Summit of the Millennium that would address the challenges of the $21^{\text {st }}$ century. Adherence to the Millennium Development Goals (MDGs) meant continuing a policy that between 1990 and $2003 \mathrm{had}$ reduced poverty from $38.6 \%$ to $18.8 \%$ and extreme poverty from $12.9 \%$ to $4.7 \%$, besides the implementation of social policies focused on a Health Reform based on the Universal Access Plan to Comprehensive Medical Services and Explicit Guarantees (AUGE); the implementation of a mandatory unemployment insurance for all workers under the rules of the Labour Code; an Educational Reform guaranteeing twelve years of compulsory and free education; and a housing policy for the poorest groups that would eradicate impromptu urban settlements.

In a similar vein, and from the perspective of international cooperation, the protection of Human Rights was assumed in the 'Initiative against Hunger and Poverty', launched in 2004 by the Presidents of Brazil, Chile and France. In addition, a year later Chile supported the fight against pandemics that contributed to poverty and socio-economic backwardness, through initiatives such as the WHO's UNITAID, which requires a small part of air ticket sales to be donated to programs to control the spread of AIDS, Malaria and Tuberculosis. The most outstanding measure was Chile's participation in the process of the political and institutional stabilisation of Haiti. The Chilean armed forces, operating under UN mandate, were deployed to the Caribbean island, so emphasising the commitment to the protection of Human Rights under a multilateral arrangement that encouraged peace, humanitarian action and the restoration of the State's capabilities. Through MINUSTAH, Chile assisted the poorest society in the region, in a joint effort with Brazil and Argentina $(\mathrm{ABC})$, and Uruguay.

During the administration of President Michelle Bachelet, the process of ratification of the Rome Statute began, and she 


\section{Human Rights, Economic Liberalism and \\ Social Affairs in Post-Pinochet Chile}

contributed to the creation of the Human Rights Council of the UN, serving as vice-president during 2008-2010. In that way she symbolised the will to give effect, in Chilean judicial law, to the recommendations, commitments and sentences of inter-American human rights bodies, in particular in the areas of freedom of speech and transparency in governance. The President gained international prestige in certain social aspects of international politics, most notably through her interest in development issues contained in the MDGs of the UN, particularly through her participation in the Network of Global Leaders for MDGs 4 and 5 (concerning child and maternal health), headed by Norwegian Prime Minister Jens Stoltenberg.

Although Human Rights have always been present on the political agenda since the return of the civilian regime, it has not been possible to assume a foreign policy of Human Rights, but rather to incorporate the subject into Chilean foreign policy. This is not to mention pending issues such as limited access to education and other basic services; increasing mortality due to diseases, poor housing; discrimination and social exclusion; and lack of participation in decision-making in the civilian, social and cultural life.

\section{The influence of the economy on politics and foreign relations}

As already stated, the guidelines of Chilean foreign policy were aimed at strengthening the country's integration into world trade, in line with its development model, and were part of the consensus between the actors who left their government and those who led the transition. Because of this, the Chilean economy experienced high growth rates when the Opposition to Pinochet took office. The imminent end of the Cold War resulted, across the hemisphere, in a passive reception of the premises of the so-called Consensus of 
Washington (Williamson 1989) ${ }^{2}$ whose political counterpart was the conclusive theories of the history of Fukuyama (1992) from the liberal-conservative field. The new leaders of the government then decided to preserve the inherited economic structure, although introducing certain adjustments that allowed some differentiation of the principles of the Chicago School of Economics and the 'Chorreo' (gushing) scheme which meant that only high economic growth would provide an end to the existing social insecurity. A new chapter now opened with the example provided by the 'German miracle' and adding to it the name 'social' to the market economy. The new ruling political coalition, called the 'Concertación por la Democracia' ('Coalition for Democracy'), combined Christian Socialism in a single political axis with positions close to the Social Democrats, and set up an economic logic of German inspiration, specifically from the Freiburg School and its 'ordoliberalism', to respond to the institutional maze inherited from the military regime without affecting the prevailing economic order. In what Garreton called a corrected neo-liberalism (Garreton 2012), there was a transit from the model of the forces of the market to a situation with the State retaining some control functions, basically oriented to inhibit the emergence of economic monopolies, over a certain subsidiary role in respect of the neediest segments of society.

In reality, the civilian governments that followed the dictatorial regime, continued with certain aspects of the road tested by the military regime derived from the physiocratic concept of economic governance. By this means, a government, more than its historical crystallisation of 'public authority', gradually acquires technical properties that are typical of the administration of the people. Foucault explains the transition from the primeval triad of security-territory-population that is typical of pre-industrial societies, to a new triad called security-population-government, typical of the contemporary world (Foucault 2007). To portray this 
triangular succession, the French intellectual started analysing the set of government practices we know as public policies, of which foreign policy is one, although with patterns of behaviour not sufficiently updated over time, or as Fuentes describes, as an 'internationalisation without modernisation' (Fuentes 2007). In this case the following questions arise: What are the consequences of a foreign policy with a basically economic orientation? What were the reasons given for not addressing other diagnostics and techniques of the social approach, the contributions from other disciplines in the social sciences? The Foucaultian answer is the problematisation of a social and political life based on economic criteria. Thus 'government' is understood from the perspective of 'economic government', which in this argumentation is restrictively defined as 'the art of exerting power in the way the economy does', by giving economic liberalism the monopolistic status of the 'art of governing'. This rationale forms regulating devices monitored by a government of technocrats, conceived as repositories of knowledge and the scientific awareness of problems faced by the State as well as the channels of resolution, without consulting the social base.

In Chile, successive democratic governments, besides re-iterating the traditional principles of Chile's foreign policy agenda and re-positioning, in the agenda, regional cooperation -under the aforementioned slogans of democratic developments and respect for Human Rights, took great pains to promote the international economic integration of the country starting from a model of open regionalism, the favourite strategy of Chilean insertion into the world since 1990. In this regard, it is plausible to argue that even when Chilean foreign policy of the governments of Patricio Aylwin (1990-1994) and Eduardo Frei Ruiz-Tagle (1994-2000), worked hard to overcome the 'vicinal' conflicts, they were recognised for the institutionalisation of trade links. Also, they implemented a non-selective multilateralism, a commercial diplomacy and notions 


\section{Gilberto Aranda Bustamante}

of democratic governance (Witker 2005: 53). Van Klaveren explains that the environment of low inter-State conflict facilitated the increase in the weight of economic issues as a result of the commercial opening which the Coalition sought to continue (Van Klaveren 1998: 122). The protectionist integration of the region was replaced by a new de-convergence around this concept of open regionalism: a concerted opening, multilateral political and economic negotiation plus the participation in multilateral regional forums that were taking shape in the world. To do that, the civilian governments deployed mechanisms that combined unilateral, multilateral, bilateral and regional openness; underlining the gradual scheme in the case of Latin America, which took advantage of the legal framework of ALADI. In 1997, Foreign Minister Insulza asserted:

The idea of economic integration has been on the agenda of Latin America for decades, but the recovery and liberalisation of the economies of the continent, the globalisation processes at a regional level and the great changes taking place on the global scene have led us to revitalise the main integration schemes and the emergence of new organisations with a great potential. This is why we define Latin America as a very important and natural sphere for the external relations of Chile (Insulza 1997: 17).

The concept of open regionalism specifically pointed to the series of actions aimed at increasing inter-dependence, especially economic cooperation among the countries of the region, as part of the continuing trend towards free flow of production factors at a global level. The origin of open regionalism in Chile was sui generis. Although inspired by Asian developmentalism, Chile did not apply it in the sense of concerted unilateral openings without reciprocity. Nor did it strictly follow the recommendations of CEPAL in the 90s by 
Human Rights, Economic Liberalism and

Social Affairs in Post-Pinochet Chile

which regional integration should be compatible with world trade. Rather, Chile rehearsed the road map of reciprocity among the signatory parties, although with no regional preferences (Fuentes 2014).

In other words, open regionalism was understood to mean that the simultaneous negotiation of economic agreements with various regional states was not mutually exclusive, but favoured the generation of overlapping regimes and was open to incorporating any possible new members (Van Klaveren 1998: 126). This mechanism facilitated greater ranges of external participation and involvement of a State member, regardless, the expected outcome of which was the diversification of its international trade. Thus, along with political re-integration, the implementation of the principle of open regionalism allowed Chile to weave a web of trade agreements that supported this trade liberalisation, ensuring various markets for the country's exports.

There was, therefore, no contradiction in signing agreements with Latin America, North America, the EU and Asia, if it was thought that such links could facilitate potential new memberships. Finally, it was understood that the deepening of regional schemes should be compatible with the liberalisation of global trade, ruling out the creation of new tariff and para-tariff barriers regarding extra-regional goods and services. In this regard, Isabel Rodriguez and Carlos Pressacco suggest:

This strategy of multiple and flexible insertion allows Chile to participate actively in the processes of regional integration in Latin America and other areas around the world, through instruments or pathways that are complementary to their opening effects: on the one side, unilateral opening that has been in place since the mid-70s, on the other, multilateral trade negotiations in which Chile 


\section{Gilberto Aranda Bustamante}

has an active role, and finally, the negotiated opening at bilateral and regional level that has been an growing trend since the beginning of the 90s. (Rodriguez and Pressaco 2005: 88)

Given the Chilean interest in balancing trade and diversifying commercial destinations one can understand why the main region with which Chile traded, the EU, was displaced in 2008 by China. Beijing led purchases within the Chilean domestic market, with a $24.2 \%$ share, while the EU took second place with $17.8 \%$, followed by Japan with $10.5 \%$. In the broader picture, we can say that in 1990 Europe accounted for $51.7 \%$ of Chilean exports, Asia $21.4 \%$, North America 14.9\%, Latin America and the Caribbean 9.6\% and other markets 2.5\%; whereas 18 years later the Asian market rose to account for $37.3 \%$ of Chilean exports, the so-called Old Continent decreased to $26.1 \%$, North America increased to $16.9 \%$, Latin America and the Caribbean to $16.1 \%$ and other markets increased their share to $3.6 \%$ (Rodriguez and Pressaco 2005: 173-174). In this regard, Carlos Portales says the diversified opening that Chile followed under the sign of openness, brought a better balance between the regions importing Chilean products, reducing dependence ranges relative to a specific market (Portales 2011).

The binomial diversification/autonomy outperformed with force, justifying the assumed pragmatism of a foreign policy poured into the gradual signing of economic agreements regardless of the premise of indispensability of a kind of openness without political content. It ensured that because of location and size Chile could not follow protectionist models that might hinder its integration into the global economy. The 'pragmatic' perspective towards the region required that the country not bow to the volunteerism that prevailed in integration strategies of yesteryear. Before any commitment to a regional bloc, Chilean governments demanded considerable flows of trade in goods and services, the establishment of coherent economic 
policies with trade openness and minimal economic stability by partners under a logic of stimulating competitiveness. In short, Chile expected the development of a regional context favourable to economic-commercial activity.

Consequently, regional convergence should seek solid economic foundations and liberalisation similar to the Chilean economy.

As a result, the Chilean insertion process within the global trade flows resulted in economic topics acquiring a relevance in Chilean foreign policy within an international context dominated by globalisation, with an economic standing and a neo-liberal openness experience stemming from 17 years of military rule. But one cannot ignore that the set of agreements signed, in addition to their commercial logic, served as a symbol of political recognition by the big players such as China, the US and the EU.

As anticipated in this economic logic, the presence that business acquired in the decision making process of foreign policy became very strong, sometimes through institutional bodies such as the Committee of Participation of the Private Sector (CPSP), created in 1995 to integrate the private business sector and labour unions in international economic negotiations or, since 2013, by participating in the Pacific Alliance by way of a corporate committee. On other occasions, indirectly through typical actions of social pressure groups such as by holding informal meetings or the practice of the so called 'adjoining room' that is to say, the space located next to the negotiating table. And although the labour unions, which had had little involvement in trade agreements in the $90 \mathrm{~s}$, were called upon in the $21^{\text {st }}$ century, their role was rather discreet. It was a corollary of the restrictions imposed by the civilian regime to the period of social mobilisations prior to the end of the military rule, in which the new government would be the defender of the pact signed between employers and unions emulating, to some extent, the political pacts 
agreed between the government and the Opposition. In other words, democratic stability required the attenuation of all social conflicts (Paredes 2011: 475). Instead, the authorities proposed the involvement of private entrepreneurs and the trade unions in a model designated by Porras as neo-corporatist to the extent that the Chilean government had social representatives in the associations of the private sector, the Confederacion de la Producción y el Comercio (Production and Trade Confederation), the Sociedad de Fomento Fabril - SOFOFA (Industrial Development Society), the Sociedad Nacional de Agricultura - SNA (National Agricultural Society, the Cámara de Comerio de Santiago (Santiago Chamber of Commerce), the Comité de Empresas Exportadoras de Servicios (Services Export Companies Committee), the Asociación de Exportadores de Manufacturas - ASEXMA (Manufactures Exporter Association) among others, making them co-responsible for decisions made in economic agreements (Porras 2003: 25). However, in practice they were not comparable to entrepreneurs and unions.

Entrepreneurs, traditionally interested in the local agenda and, at the most, by the 'vicinal' contingencies in foreign conflicts that might potentially affect their business, gradually became involved in territorial disputes, such as the latest episodes in the maritime de-limitation between Chile and Peru, in which the said actors strongly supported the policy of 'cuerdas separadas' ('separate strings') that issued from Lima. ${ }^{3}$ With all before it, by the end of the $20^{\text {th }}$ century the interest of the private sector required a government interlocutor able to speak in such terms.

In this sense, it is important to point out the great influence of the business group responsible for the negotiation of trade agreements, known as the Dirección General de Relaciones Económicas Internacionales - DIRECON (General Directorate of International Economic Relations). Created in the late 70 s by the military regime and subsequently strengthened in terms of its role since the 
beginning of the civilian government, it has become the formal expression of the State in the specialised attention given to the national development model oriented to the exterior. A centralised unit with some degree of autonomy in its management unit compared with the truss work of the chancellery. Although it is formally incorporated into the structure of the Ministry of Foreign Affairs, its composition meets the aforementioned technical criteria of having specialists in economic knowledge, which in practice means operating in parallel to the traditional formal diplomatic service structure; hence its nickname of 'parallel diplomacy'. Consultation with employers was conducted through that route, given its less bureaucratic, less elitist and more professional character (Wilhelmy 2015). DIRECON led this kind of parallel diplomacy specialising in trade issues, which highlighted the economic development of Chile to potential investors, multiple international cooperation and, particularly, the conclusion and implementation of economic inter-State agreements (Aguayo 2012: 224). To that end, it relied on specialised units for traditional bilateral economic issues and to others whose expertise was the promotion of exports.

\section{Social echoes: the emergence of sub-national partnerships}

Despite the dominance of the economist principle on social participation in foreign policy, this did not completely eclipse the other social dynamics and logics of action in the area. Just as with the paradigmatic innovation of scientific disciplines (Thomas Kuhn 1962) the change of participatory logic remained within the margins, taking advantage of the gaps in the political and economic system by deploying the dynamics of a potential democratiser of foreign policy. Chilean economic liberalism proposed that non-state actors should associate mainly with the purpose of developing trade and getting 


\section{Gilberto Aranda Bustamante}

benefits for the sector, especially if that association contemplated extra-national participants considering that their economic activity was mainly oriented to external markets.

In this regard, it is important to mention the outstanding role played by bi-national committees as in the cases of Argentina and Chile. This practice was established in the South American region in 1979 by an agreement signed in Ciudad del Este by Paraguay and Brazil. With regard to Chile, the preparations for the Peace and Friendship Treaty of 1984 with Argentina brought about the establishment of the Frontier Committee of Cristo Redentor in April 1986 in connection with the meeting of the Bi-national Commission for Cooperation and Physical Integration of Chile and Argentina. Its goal was to improve commercial traffic, optimising bureaucratic management for the transit of people and goods. By the 90s it was clear that the original economic requirements had been exceeded, so - as Silva and Moran explained - both States began to discuss matters of mutual interest within the framework of the Committee (Silva and Moran 2010: 301). As a result, a regulation was drafted in 1997, which paved the way for a qualitative change verified in a new title: Border Committees gave way to Committees on Integration, and thus a multiplication of its participants, functions and parameters of action, consolidating the density of micro-binational relations, but with greater oversight by the member States. In 2006, there were eight of these committees: NOA-Norte Grande, ATALCAR, Agua Negra, Las Leñas, Paso Cristo Redentor, El Pehuenche, the Lake Region, and Austral Integration. Thus, through a State action, that resulted in the recognition of sub-national links, an important role was given first to the regional and provincial governments, and later to various social sectors, in a process of basal integration seeking to strengthen multi-level governance of outlying areas by national centres. Locations to gather together national, provincial and local authorities, and the representatives of NGOs, universities and 
entrepreneurs were formalised. The new dynamic was formally incorporated in a new Regulation of Integration Committees in 2011; an integration that clearly incorporated both private non-profit organisations and private entrepreneurs. Control of the agenda was retained by a de-centralised State through regional and provincial representatives.

This required a renewed involvement of social sectors other than the traditional market, for example ethnic organisations, as was the case of the Aymaras Without Borders Strategic Alliance (EA), technically an association of rural municipalities that from an Andean perspective generated links with similar organisations in Bolivia and Peru. This partnership brought together 56 municipalities in the three aforementioned states with a representation of 180000 people. Although it used the connection of non-central government actors, its origin is local social. Additionally, it has deftly manoeuvred itself to interact at the international level with bodies such as the Inter-American Development Bank (IDB) and the Italian NGO CESPI, among others. In Chile, it settled in the towns of Putre, General Lagos and Camarones in the region of Arica-Parinacota, plus Pozo Almonte, Pica, Colchane and Camiña in the region of Tarapaca. At the same time, the departments of Tacna in Peru and Oruro, Potosi and La Paz in Bolivia (Gonzalez, Rouviere and Ovando 2008) joined the Alliance. Its originality lies in the effort to manage the difficulties faced by the Aymara - descendent communities that lived in the triple high Andean border - such as deficits in infrastructure and services, tariff barriers and policies that hindered a sustainable development in a manner that was consistent with their ancestral life styles and their particular border habitat. A populous creating their own methodologies of participation.

The existing reality prior to the emergence of this type of initiative was the absence of common plans for the management of the shared 


\section{Gilberto Aranda Bustamante}

territory that would integrate the cultural uses of the land: the legislative divergence in phyto-sanitary trading issues that affected exchanges historical carried out by the Aymara communities (alpacas and llamas, quinoa, medicinal and aromatic plants), together with an intensive process of de-population of a region experiencing limited job opportunities and disconnection in the road networks. We must not forget that the region is highly important to the State for its geopolitical scope and is very susceptible to crimes such as the smuggling of electronic goods and vehicles (González 2012: 298), and that the integral development was wasted serving the traditional forms of life. This situation encouraged the formation of Aymaras without Borders in 2001, whose first demand of the State was implementation of cross-border economic improvement projects that incorporated the society and the Aymara culture (Vásquez 2011). AE deployed an international strategy to give more direct resistance, or to bypass the State that took advantage of the opportunities offered by the domestic and international system.

The enormous distance from the decision-making centre (two thousand kilometres in the case of Santiago) gravitated critically on the Andean identity claim that intended to re-articulate a vernacular space under accord 169 of the International Labour Organisation (ILO) Convention. This does not mean that Aymaras without Borders slid towards autonomy positions, but rather re-introduced a divergent imaginary space (Filibi 2010: 26) to those produced by modern State conventions that demarcated borders. Thus, the dual character of an instrumental and symbolic type of paradiplomacy is confirmed when adding to the economic content (sustainable development) the communicative action directed to the reproduction of an ancient collective identity through the affirmation of their cultural representation (Cornago 2010: 123). Aymaras without Borders is a challenge in itself for the elites of the States, the moment it starts questioning the centralisation of diplomatic activity 


\section{Human Rights, Economic Liberalism and \\ Social Affairs in Post-Pinochet Chile}

(Cornago 2012) by criticising the historical process of centralised resource management. Rather elusive to co-optation by States uncomfortable with the international scope of that experience, $\mathrm{AE}$ demanded administrative reforms wielding them in larger forums such as the Border Committees. AE even touches a chord further if we consider that this area of cross-border interaction was the scene of the Pacific War (1879-1883) with diplomatic consequences that have existed until today. Additionally, those imagined territorial dynamics, concerning territories in several nation-states, is also a manifestation of what Philips and Soldatos called the 'internalisation of international politics' (Philips and Soldatos 1996: 212). It testifies to the deep inter-penetration of local and regional, national and international spheres. This is another challenge both for national governments and for their local expressions. While the former tend to understand these processes as a 'threat', the latter must cultivate skills in the management of cross-border interdependence and thus optimise their own territorial development.

In summary, a method of social origin that implements the role of sub-State border actors to promote a certain type of sub-regional integration (González 2012: 305), aimed at consolidating an identity that goes beyond the conventions of each State, and that expresses a shared cultural heritage (Letamendia, Morata F and Paredes 2011; Rouviere 2009; González, Rouviere and Ovando 2008).

\section{Conclusions}

Since the beginning of the transition to civilian rule, Human Rights have constituted a motto of the political agenda in Chile. At the turn of the century, Chile acquired a symbolic commitment to this issue as evidenced by the active participation of Chile in multilateral forums of social inclusion. However, it is not possible to speak of a foreign policy of Human Rights but rather a topic incorporated into Chilean foreign policy. Much more important has been the economic 
governance of Chile, one of the seals in the past quarter century. This aspect resulted in a Foreign Policy mobilised by the signing of FTAs that responded to a strategy of open regionalism. Therefore, the higher dose of social action in its foreign road map was starred by entrepreneurs who won spaces. In this picture, however, there are certain gaps with a democratising potential particularly from the sidelines. The Aymaras without Borders experience is a concrete case of using paradiplomatic mechanisms, typical of rural indigenous municipalism, of symbolic content that has re-appropriated their ancestral habitat by the re-positioning of a cultural 'alto-Andean' identity before State agencies and international actors. Aymaras Without Borders reveals the shift in diplomatic practice as an exclusive tool of the States to re-establish themselves in base social communities, even in contexts that do not favour the participation of the whole society in the design of its foreign policy.

\section{References}

Aranda, Gilberto. 2004. 'Vicaría de la Solidaridad, una Experiencia sin Fronteras'. Santiago: Ediciones CESOC.

Anderson, Perry. 1981. Las Antinomias de Gramsci. Estado y Revolución en Occidente. Barcelona: Editorial Fotamara.

Aguayo, Marco. 2012. 'El servicio diplomático de Chile principal herramienta de la ejecución de la política exterior chilena'. In Mario Artaza and César Ross. La política exterior de Chile, 1990-2009: del aislamiento a la integración global. Santiago: RIL Editores. pp. 205-238.

Constitución Política de la República de Chile. 2006. Editorial Jurídica de Chile.

Cornago, Noé. 2013. Plural Diplomacies: Normative Predicaments and Functional Imperatives. Amsterdam: Martinus Nijhoff Publishers. 


\section{Human Rights, Economic Liberalism and Social Affairs in Post-Pinochet Chile}

.2013b. 'Diplomacy decentralised: subnational politics and the making of sustainable diplomatic couples in Latin America'. In Brigitte Vassort-Rousset (ed). Building Sustainable International Couples: Critical Components of a Strategy Towards Peaceful and Constructive Cooperation. Basingstoke: Palgrave.

2012. Diplomacy decentralised: sub-national politics and the making of peaceful and durable diplomatic couples in Latin America. Bilbao: Universidad del país Vasco (Manuscript).

2010. 'La descentralización como elemento de innovación diplomática: aproximación a sus causas estructurales y lógicas de acción'. In Luis Maira (ed). La política internacional subnacional en América Latina. Buenos Aires: El Zorzal. pp. 107-134.

2009. 'La diplomacia como heterología'. Facultad de Ciencias Sociales y de la Comunicación, Leioa, España, Departamento de Derecho Internacional Público, Relaciones Internacionales e Historia del Derecho y de las Instituciones de la Universidad del País Vasco (Manuscript).

Easton, David. 1963. The Political System: an inquiry into the state of political science. New York. Alfred A Knopf.

Echeverria, Gloria, Francisco Orrego and Luz O'Shea. 1982. 'Los intereses de Chile en el Pacífico', Revista de Educación, № 96, Santiago. pp. 12.

Filibi, Igor. 2010. 'Dancing spatialities around a geopolitical continuity: the Silk Road'. 5-Spaces of global capital: Territoriality, markets and democratic politics. Estocolmo: SGIR Pan-European Conference, September 9-11.

Foucault, Michel. 2007. Seguridad, Territorio y Población. Curso en el Collége de France 1977-1978. Translated by Horacio Pons. Buenos Aires: Fondo de Cultura Económica.

Fuentes, Claudio. 2007. 'Internacionalización sin “modernización: el caso del Ministerio de Relaciones Exteriores de Chile', América Latina Hoy, n. 46, pp. 97-117.

Fuentes, Cristian. 2014. 'La política exterior de la transición chilena desde sus fuentes internas', Si Somos Americanos, vol. 14, n. 2, Santiago, pp. 133-157.

Fukuyama, Francis. 1992. El Fin de la Historia y el último hombre. Barcelona: Editorial Planeta. 


\section{Gilberto Aranda Bustamante}

. 1995. 'Culture's primacy and Democracy future', Journal of Democracy, Vol. 6, № 1, Baltimore: John Hopkins University Press, pp. 7-14.

Garretón, Manuel Antonio. 2012. Neoliberalismo Corregido y Progresismo Limitado. Los gobiernos de las concertación en Chile, 1990-2010, Buenos Aires: Editorial Arcis-CLACSO.

González, Sergio, Laetitia Rouviere and Cristian Ovando. 2008. 'De Aymaras en la frontera a Aymaras sin fronteras. Los gobiernos locales de la triple-frontera andina (Perú, Bolivia y Chile) y la globalización'. Diálogo Andino 31, pp. 31-46.

González, Sergio. 2012. Sísifo en los Andes la (frustrada) integración física entre Tarapacá y Oruro: las caravanas de la amistad de 1958. Santiago de Chile: RIL.

Kuhn, Thomas. 2005. La Estructura de las Relaciones Científicas (1962). Madrid: Fondo de Cultura Económica.

Ovando, Cristian and Sergio González. 2012. 'La política exterior chileno-boliviana en la década de 1950 mirada desde la región de Tarapacá: una aproximación desde el diálogo entre las teorías de las percepciones y el realismo neoclásico', Polis 11/32, pp. 461-492.

Portales, Carlos. 2011. 'Desafíos para la política exterior en las próximas décadas: Chile y la región en un mundo global'. In Estudios Internacionales. № 169. Santiago de Chile.

Rouviere, Laetitia. 2009. 'Un territorio político transfronterizo? Formas de legitimación de una experiencia de legitimación de una experiencia de acción política intermunicipal', Si Somos Americanos. Revista de Estudios Transfronterizos, 9/2, pp. 13-29.

Insulza, José Miguel. 1997. 'La Política Exterior chilena y su relación con la Seguridad y Defensa del país'. Política y Estrategia. № 72 . Santiago de Chile, pp. 10-31.

Lagos, Ricardo. 2001. 'Chile en un mundo en cambio'. In Foreign Affairs en Español. Primavera. México.

Letamendia, Francisco, Francesc Morata, Oscar Paredes, Elías Condori and Vicente Alancoa. 2011. Pueblos y fronteras en los Pirineos y el altiplano andino. Madrid: Editorial Fundamentos. 


\section{Human Rights, Economic Liberalism and Social Affairs in Post-Pinochet Chile}

Ministerio de Relaciones Exteriores de Chile. 1992. La Política Exterior de Chile: Discursos de S.E. el Presidente de la República don Patricio Aylwin Azócar y del Ministro de Relaciones Exteriores don Enrique Silva Cimma. Santiago de Chile.

Montobio, Manuel. 2004. 'La cultura y los nuevos espacios multilaterales', Pensar Iberoamérica, Revista de Cultura, Organización de Estados Iberoamericanos para la Educación, la Ciencia y la Cultura, № ${ }^{\circ}$, septiembre diciembre.

Paredes, Juan Pablo. 2011. 'Ciudadanía, Participación y Democracia. Deuda y Déficit en los 20 años de Democracia en Chile', Polis, v. 10, n. 28, Santiago, abr, pp. 473-499.

Philip, Christian and Panayotis Soldatos (eds). Au-delà et en deçà de l'État-Nation, Bruselas, Bruylant, 1996.

Porras, José Ignacio. 2003. 'La estrategia chilena de acuerdos comerciales: un análisis político', Serie Comercio Internacional, (Vol. 36). Santiago: CEPAL.

Portantiero, Juan Carlos. 1981. Los Usos de Gramsci. México: Folios Ediciones.

Putnam, Robert. 1988.'Diplomacy and Domestic Politics: The Logic of Two-Level Games'. International Organisation, Vol. 42, № 3, pp. 427-460.

Quezada, Abraham. 2010. 'Inserción Internacional de Chile en la Post-Guerra Fría. Concertación política e integración económico-comercial; dos ejes conceptuales de la política exterior en el Gobierno de Ricardo Lagos (2000-2006)'. Enfoques. Vol. VIII, № 13. pp. 119-134.

Rodríguez, Isabel and Carlos Pressacco. 2005. 'Chile y los procesos de integración regional en América Latina: su asociación con el MERCOSUR'. Si Somos Americanos. Vol. VII. № ${ }^{0}$. Santiago de Chile.

Silva Soura, Verónica and Carlos Morán León 2010. 'Relaciones subnacionales. El caso de Chile-Argentina'. In Luis Maira (ed). La Política Internacional subnacional en América Latina. Bueno Aires: Libros el Zorzal, pp. 259-303.

Van Klaveren, Alberto. 1998. 'Inserción internacional de Chile'. In Cristián Tolosa and Eugenio Lahera (eds). Chile en los noventa. Presidencia de la República. Santiago de Chile.

Vásquez, José Antonio. 2012. 'Aymaras sin fronteras... un nuevo reto' Available at <http://joseantoniovasquezm.blogspot.com/2011/04/ aymaras-sin-fronteras-un-nuevo-reto.html>. Accessed on 15-04-2013. 


\section{Gilberto Aranda Bustamante}

Wapner, Paul. 1997. 'Governance in Global Civil Society'. In Oran Young (ed). Global Governance. Drawing Insights from the Enviromental Experience, Cambrige: The MIT Press, pp. 65-84.

Wilhelmy, Manfred. 2015. 'Los Empresarios y la Política Exterior'. In Mario Artaza and César Ross (ed) La Política Exterior de Chile, 1990-2009. Del aislamiento a la integración regional, Vol. 2. Santiago: Ril Editores, pp. 57-78.

Witker, Iván. 2005. 'La política exterior de Chile frente a la teoría de las Relaciones Internacionales. 1990-1999'. Bicentenario. Revista de Historia de Chile y América. 4(1). Santiago de Chile.

\section{Notes}

1. Although, equally, it should be noted that the treaty with the USA was threatened by the refusal of Santiago to support this country in the Iraq War, during Chile's tenure as a non-permanent member of the UNSC. Earlier, Chile had occupied a non-permanent seat on the UNSC during the periods 1952-1953, 1961-1963 and 1996-1997.

2. Among other policies, the framework of the Washington Consensus included: a) fiscal discipline; b) encouraging private initiative; c) liberalisation of markets; d) progressive low tariff that may allow foreign economic opening; and, e) export promotion.

3. The 'separate strings' supposed that political territorial disputes followed a track other than the one used for economic exchanges, and that they did not affect each other.

\section{About the Author}

\section{Gilberto Cristian Aranda Bustamante is}

Associate Profesor of the Institute of International Studies, University of Chile, and researcher of the Institute of International Studies, University Arturo Prat. He has received his $\mathrm{PhD}$ in Latin American Studies from the University of Chile, and his Master's degree in Latin American Social and Political Studies from Jesuita Alberto Hurtado University. He has also a MA in International Studies from the University of Chile, and a MA in Human Rights from the 


\section{Human Rights, Economic Liberalism and \\ Social Affairs in Post-Pinochet Chile}

International University of Andalucía. He has received his BA in History and Journalism from the University of Chile. His research topics include: Latin American Integration, Religion and Politics, and Populism in Latin America. He has published several books and articles in indexed journals. 